\title{
Soil Moisture Distribution as Influenced by Deficit Irrigation through Drip System in Maize
}

\author{
A. Bharathi ${ }^{1 *}$, T. $\operatorname{Ragavan}^{1}$, V. Geethalakshmi ${ }^{1}$, A. Rathinasamy $^{2}$ and R. Amutha ${ }^{3}$ \\ ${ }^{1}$ Department of Agronomy, AC \& RI, TNAU, Madurai-625104, TN, India \\ ${ }^{2}$ Department of Soils and Environment, AC \& RI, TNAU, Madurai-625104, TN, India \\ ${ }^{3}$ Unit of Crop Physiology, AC \& RI, TNAU, Madurai-625104, TN, India \\ *Corresponding author
}

\section{Keywords}

Deficit irrigation,

SMC, Distribution

pattern, ADI

Article Info

Accepted:

17 May 2018

Available Online:

10 June 2018

\section{A B S T R A C T}

Field experiment was conducted during 2017 to study the effect of deficit irrigation practices through drip system and soil moisture distribution in maize. Creation of soil moisture gradient is indispensable to explore the beneficial effects of partial root zone drying (PRD) irrigation and it could be possible only through alternate deficit irrigation (ADI) practice in paired row system of drip layout, which is commonly practiced in India. In the present study, PRD and deficit irrigation (DI) concepts (creation of soil moisture gradient) were implemented through alternate deficit irrigation (ADI) at two levels of irrigation having full and partial application at 60, 80 per cent $\mathrm{PE}$ as well as $\mathrm{ET}_{\mathrm{c}}$ based levels using drip system, comprised of seven irrigation levels. The results of the experiment showed that, irrespective of the levels of irrigation, SMC was low at $30 \mathrm{~cm}$ distance from the plant both across as well as along the laterals. The reduction in the SMC also recorded corresponding to the decreased level of water application (at all the locations). Further, it was observed that the alternate deficit irrigation (ADI) concept exerted with uneven distribution of moisture in the levels of both PE based irrigation application as well as $\mathrm{ET}_{\mathrm{c}}$ based. Among the ADI treatments, ADI as 80 and 60 per cent PE had less uneven distribution than ADI as 80 and 60 per cent ETc based irrigation.

\section{Introduction}

Water is one of the most precious and heavily scrutinized natural resource worldwide. Particularly in arid regions and in parts of the world that have limited water resources improving agricultural water use efficiency is vitally important. Innovative irrigation solutions must address the water scarcity problems affecting arid countries. Advanced irrigation technologies, such as drip and sprinkler irrigation, are more efficient than traditional surface methods to achieve higher crop and water productivity (Sivanappan, 1998). Deficit (or regulated deficit) irrigation is one way of maximizing the water use efficiency (WUE) for higher yield per unit of irrigation water applied. The goal of deficit irrigation (DI) is to increase crop WUE by reducing the amount of water at irrigation or by reducing the number of irrigation events (Kirda, 2002). Under DI, crops are deliberately exposed to water stress, which may consequently lead to yield reduction 
(Prichard et al., 2004; Smith et al., 2002; Zhang et al., 2004). Drip irrigation has been practised for many years for its effectiveness in reducing soil surface evaporation, increasing the crop yield and WUE (Sivanappan, 2004). Now it has been widely used in horticultural and wide-spaced agricultural crops to tackle the problem of water scarcity. In addition to DI, Partial Root zone Drying (PRD) is also a promising practice for inducing stress tolerance in some agricultural and horticultural crops (Kirda, 2002; Prichard et al., 2004; Gencoglan et al., 2005). The DI and PRD systems require high management skills. Micro-irrigation technology facilitates the application of DI and PRD.

Drip irrigation systems generally consist of drippers that have discharge rate varying from 2.0 to $8.0 \mathrm{l} / \mathrm{h}$. The relationships between application rates, soil properties, and the resulting water distribution for conventional drippers are well documented (Bresler et al., 1982). The wetting patterns during application generally consist of two zones; (i) a saturated zone close to the drippers and (ii) a zone where the water content decreases toward the wetting front. Increasing the discharge rate generally results in an increase in the wetted soil diameter and a decrease in the wetted depth (Ah Koon et al., 1990 and Assouline, 2002). Consequently, the water application rate is a factor, which determine the moisture distribution around the dripper and the related root distribution and plant water uptake patterns. Keeping all this in view, this research was undertaken to study the moisture distribution pattern under various levels of deficit irrigation as implemented through drip system.

\section{Materials and Methods}

Field experiment was conducted at Agricultural College and Research Institute,
Tamil Nadu Agricultural University, Madurai, to study the effect of varying deficit irrigation regimes in maize under drip irrigation system during summer, 2017. The experimental soil was texturally classified as sandy clay having 25.2 per cent field capacity, 12.5 per cent permanent wilting point and has $1.36\left(\mathrm{~g} \mathrm{cc}^{-1}\right)$ bulk density. Soil has $\mathrm{pH}$ value of 7.95 , organic carbon content of 0.36 per cent and EC of $1.55 \mathrm{dsm}^{-1}$. The available status of nitrogen in the soil was low $\left(264 \mathrm{~kg} \mathrm{ha}^{-1}\right)$, with medium phosphorus $\left(18.5 \mathrm{~kg} \mathrm{ha}^{-1}\right)$ and high in potassium $\left(378 \mathrm{~kg} \mathrm{ha}^{-1}\right)$. The experiment was laid out in a randomized block design and the treatments were replicated thrice. Treatments comprised of seven irrigation levels through drip (Table 1). Drip irrigation system was operated once in three days and irrigation was applied as per the treatments based on PE and $\mathrm{ET}_{\mathrm{c}}$ levels.

The experimental field was thoroughly ploughed. Beds were formed in the dimensions of $120 \mathrm{~cm}$ width, $30 \mathrm{~cm}$ furrow and $15 \mathrm{~cm}$ height. Buffer channels were formed to control the lateral seepage of water from one plot to another. The plot size was 7.2 $\times 4.5 \mathrm{~m}$, accommodating six rows of crop. Maize hybrid COHM-6, was used for the experimental study. Seeds were hand-dibbled at the rate of one per hole. Paired row spacing of $120+30 \times 60 \mathrm{~cm}$ was followed. Sowing irrigation was uniformly given to all treatments. The depth of irrigation was fixed as $5 \mathrm{~cm}$.

Water requirement (litres per day or Lpd) or $\mathrm{ETc}=\mathrm{CPE} \times \mathrm{Kp} \times \mathrm{Kc} \times \mathrm{Wp} \times \mathrm{S}$,

$\mathrm{PE}=\mathrm{CPE} \times \mathrm{K}_{\mathrm{p}}$

Where,

$\mathrm{ETc}=$ crop evapotranspiration,

$\mathrm{CPE}=$ cumulative pan evaporation $(\mathrm{mm})$, 
$\mathrm{Kp}=$ pan factor (0.8) (Vijayalakshmi, 2003),

$\mathrm{Kc}=$ crop coefficient,

$\mathrm{Wp}=$ wetting area percentage (80\%) (Veeraputhiran, 2000),

$\mathrm{S}=$ Crop spacing $(0.75 \times 0.25 \mathrm{~m}$ for maize $)$.

Irrigation water was pumped from the water source and conveyed to the main line of 63$\mathrm{mm}$ outer diameter (OD) polyvinyl chloride (PVC) pipes after filtering through sand filter. In the main line, venturi was installed for fertigation. From the main, sub-mains of 40 $\mathrm{mm}$ OD PVC pipes were drawn, and from the sub-main, laterals of 12-mm low linear density polyethylene (LLDPE) pipes were installed at an interval of $1.2 \mathrm{~m}$. Each lateral was provided with individual tap control for imposing respective irrigation schedules. Along the laterals, inline drippers with a discharge capacity of $4 \mathrm{~L} \mathrm{hr}-1$ were spaced at $0.4 \mathrm{~m}$. Single lateral was used for a paired row of maize.

Sub-mains and laterals were closed at the end with end cap. After installation, trial run was conducted to assess mean dripper discharge and uniformity coefficient. This was taken into account while fixing the irrigation water application time. During the irrigation period an average of $90-95 \%$ uniformity was observed.

Soil moisture content was estimated by gravimetric method. Soil sample were taken at a spacing of $0,10,20$ and $30 \mathrm{~cm}$ across the lateral and 10,20 and $30 \mathrm{~cm}$ along the lateral and at a depth of 0-10, 10-20, 20-30, 30-40 and $40-50 \mathrm{~cm}$ for studying soil moisture distribution pattern in each drip irrigation regime. Sampling was made after irrigation, 24 hours after irrigation and 48 hours after irrigation at silking stage. The wet weight (Ww) was determined and the samples were oven dried at $105^{\circ} \mathrm{C}$ for 24 hours (Farbrother, 1973). The data were collected before the start of irrigation during silking stage to show the SMC under drip irrigation at various locations from dripper and away from the plant. The percentage of moisture content (\% Mc) on dry weight basis was calculated as:

Percentage of moisture content $(\% \mathrm{Mc})=$ $[(\mathrm{Ww}-\mathrm{Dw}) / \mathrm{Dw}] \times 100$

Where,

$\mathrm{Ww}=$ Wet weight $(\mathrm{g})$

Dw $=$ Dry weight $(\mathrm{g})$

Temporal and spatial movement of soil moisture was studied by using the soil moisture data. Graphical software package SURFER was used to show the three dimensional view of soil moisture vertically and horizontally from the emitter.

\section{Results and Discussion}

The soil moisture contents estimated at different depths and distances from emitter were analysed and plotted graphically as contour maps (Fig 1-7).

The data on the soil moisture distribution showed that under CDI at 100 per cent with IW/CPE ratio at $0.75\left(\mathrm{~T}_{1}\right)$ the soil was wetted uniformly wetted throughout the irrigation cycle (Fig 1). Further it was observed that, soil water content was low in the treatments received less water and more in well watered treatments (Philip, 1971). It was evident in the plots irrigated with 80 and 60 per cent PE and ETc $\left(T_{2}-T_{5}\right)$, the moisture content was near equal and then decreased below field capacity $(25.2 \%)$ as the amount of water decreased. Irrigation applied under 60 per cent PE and $E_{c}$ showed lesser SMC in all the sampling points when compared to other treatments (Fig 4 and 5). 
Fig.1-7 Soil moisture distribution across the lateral (on left) and along the lateral (on right) under Deficit irrigation practices
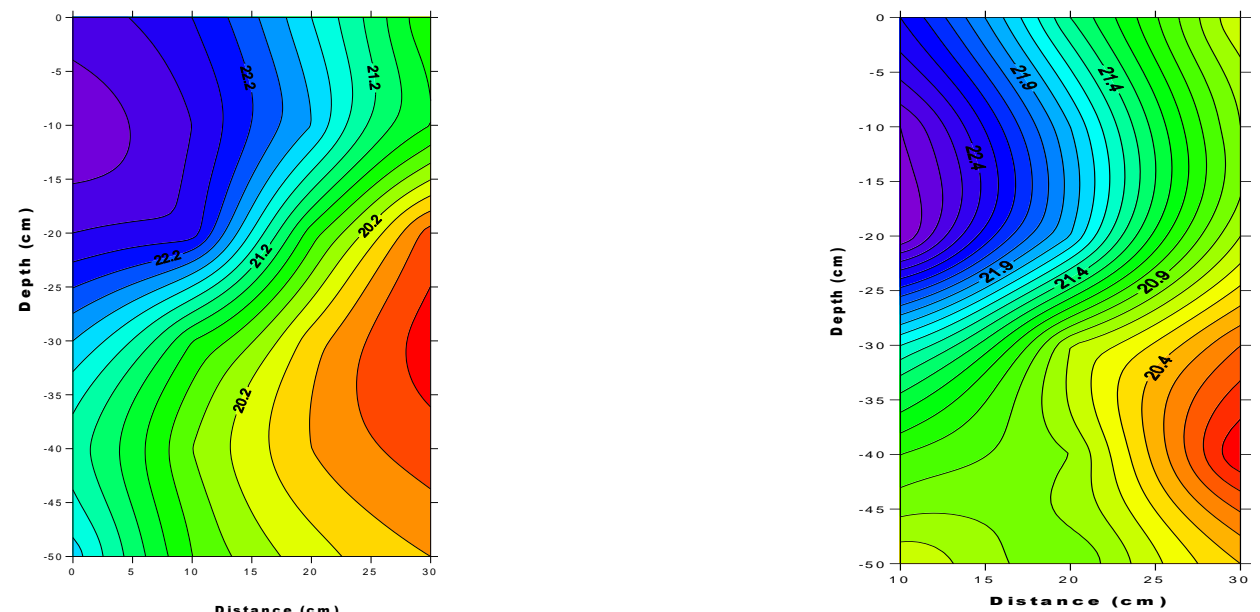

Fig.1 Conventional Irrigation at IW/CPE of $0.75\left(\mathrm{~T}_{1}\right)$
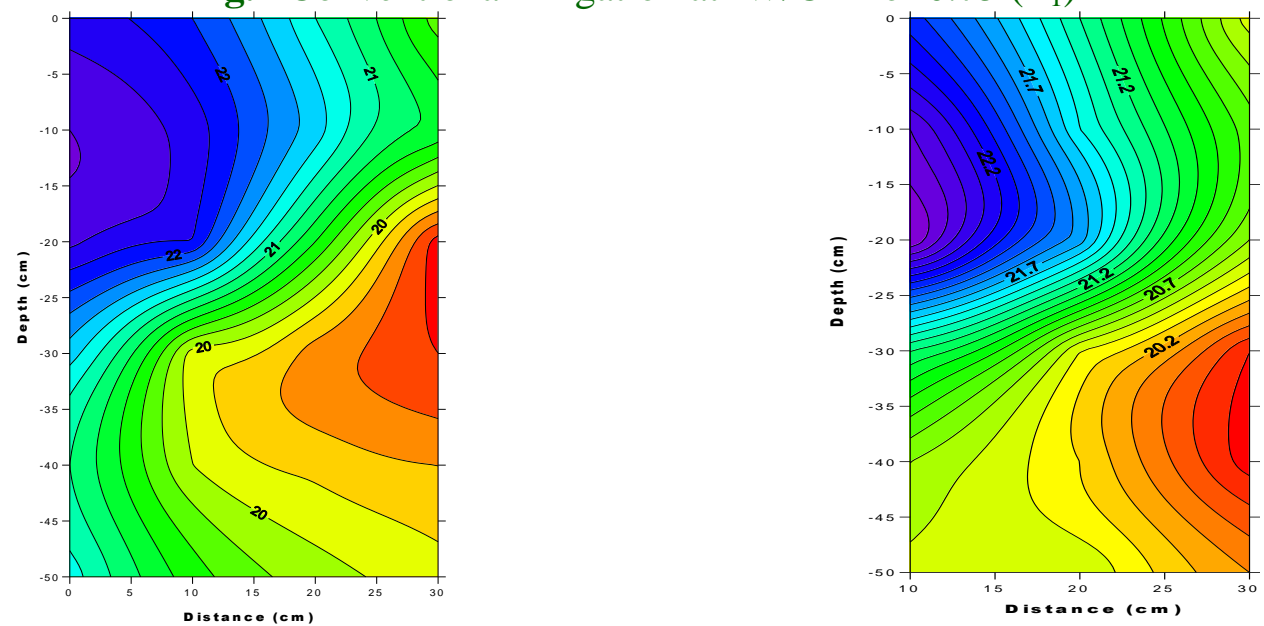

Fig.2 Irrigation at $80 \% \mathrm{PE}\left(\mathrm{T}_{2}\right)$
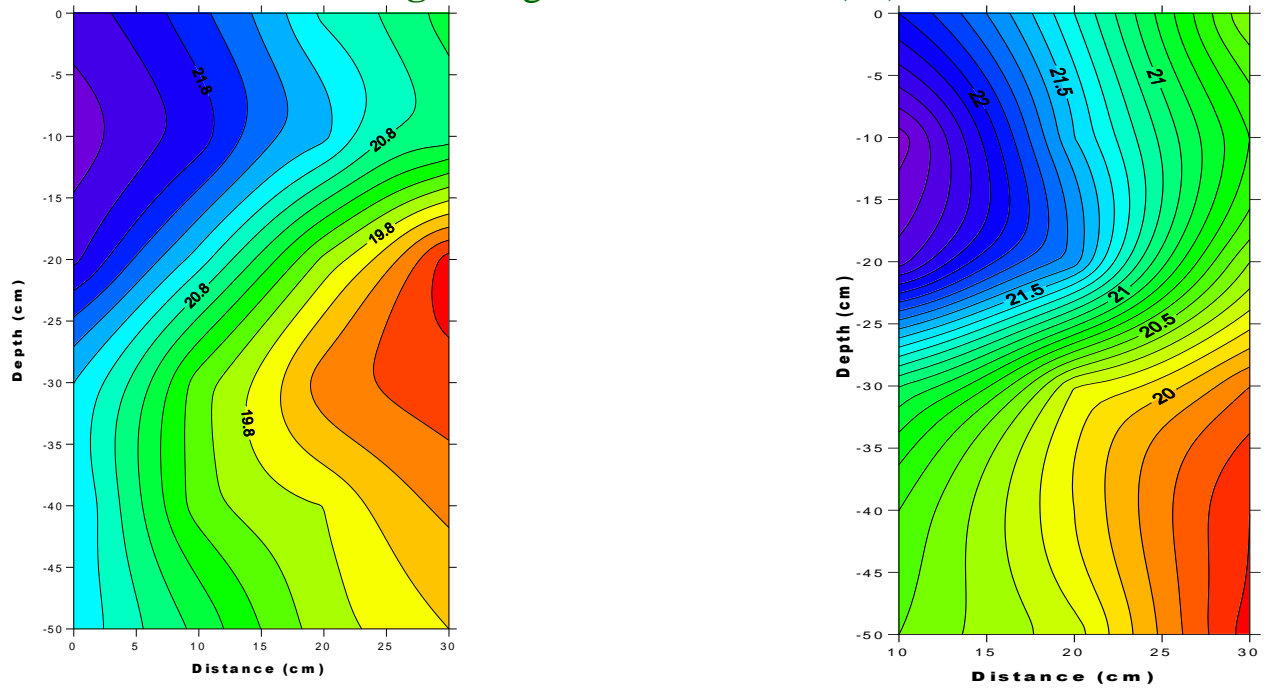

Fig.3 Irrigation at $80 \% \mathrm{ET} \mathrm{c}\left(\mathrm{T}_{3}\right)$ 

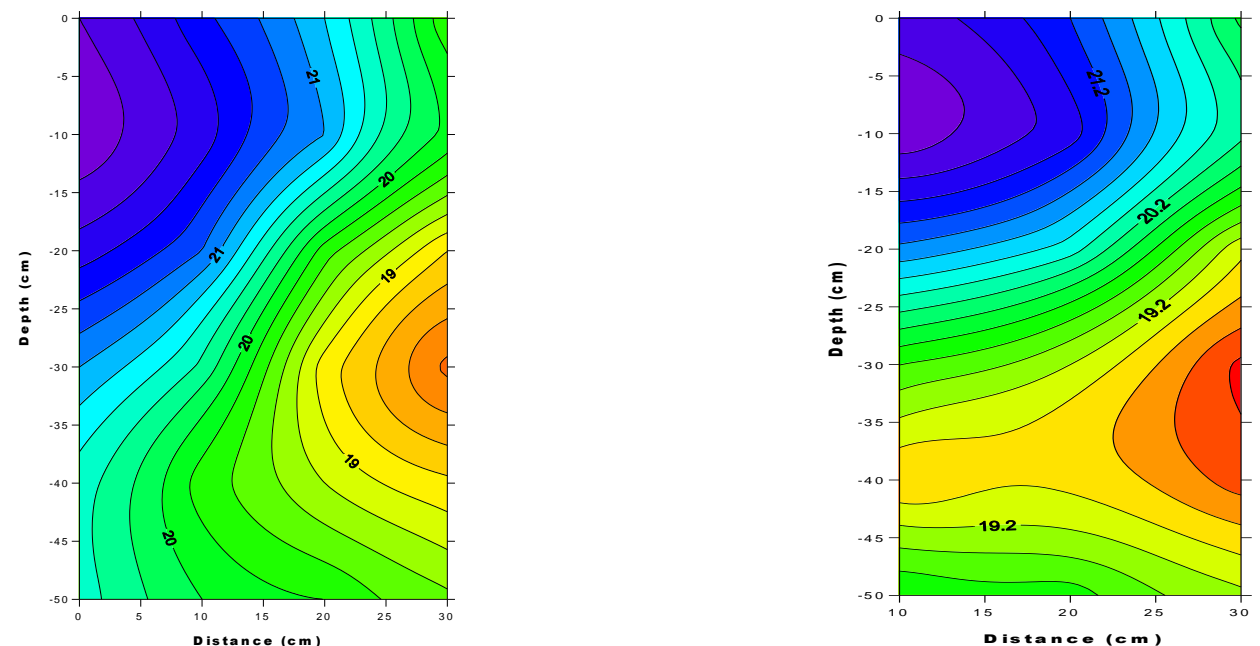

Fig.4 Irrigation at $60 \% \mathrm{PE}\left(\mathrm{T}_{4}\right)$
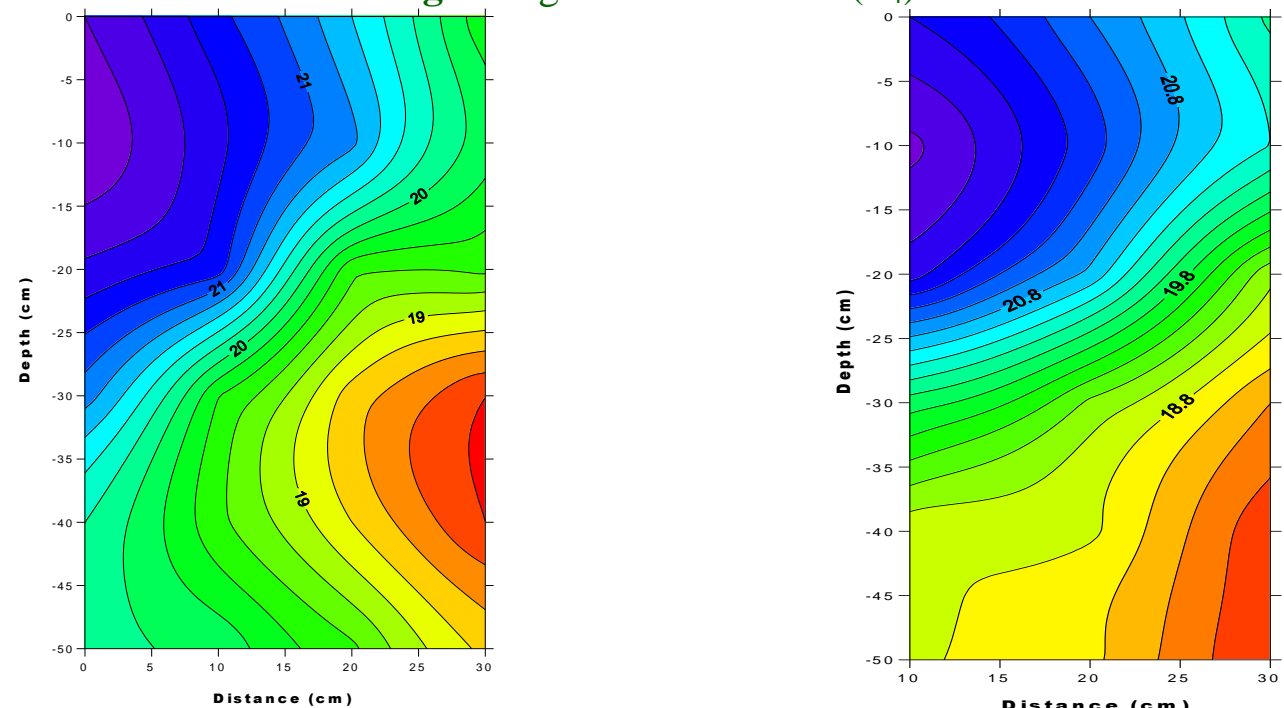

Fig.5 Irrigation at $60 \%$ ETc $\left(\mathrm{T}_{5}\right)$
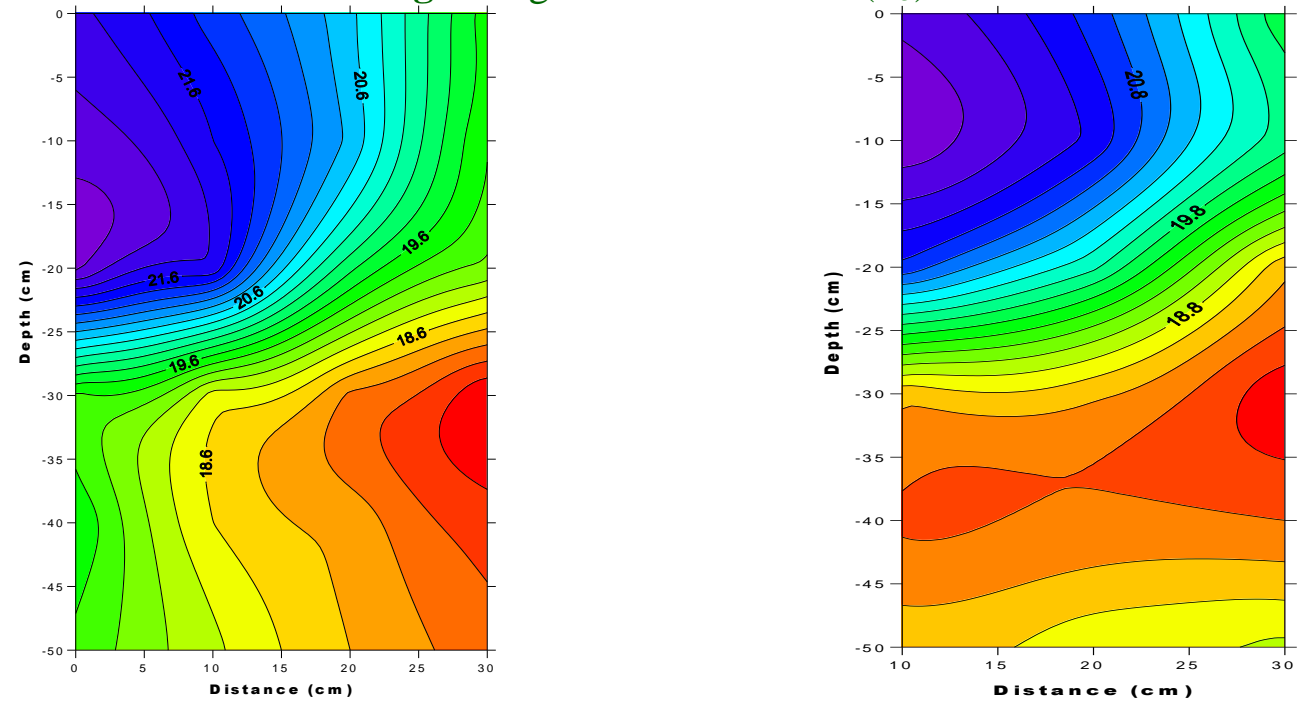

Fig.6 80 and $60 \%$ PE as ADI $\left(\mathrm{T}_{6}\right)$ 

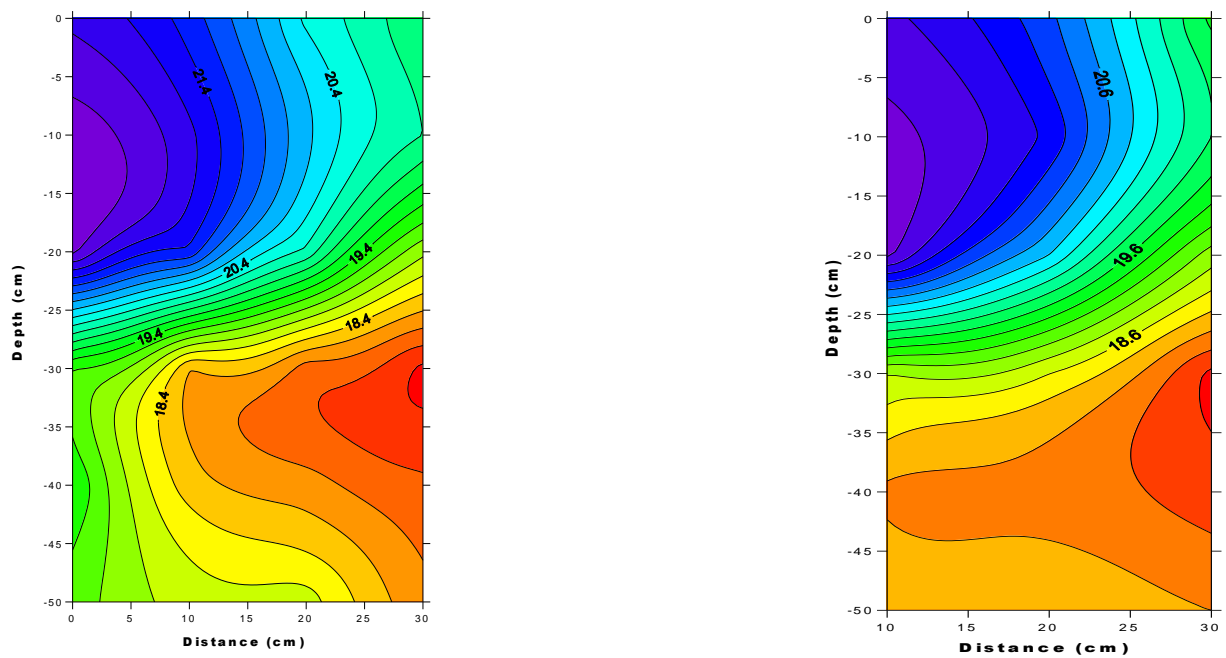

Fig.7 80 and $60 \%$ ET c as ADI $\left(\mathrm{T}_{7}\right)$

Table.1 Treatment details

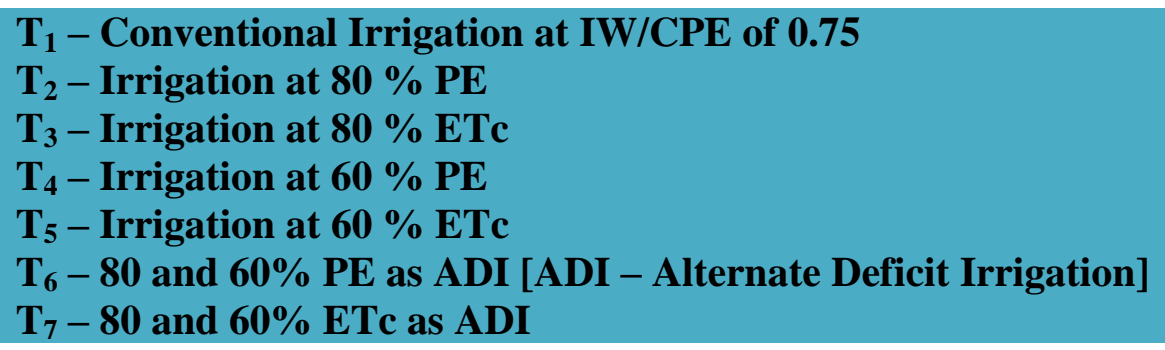

It was observed from the figures that the moisture content gradually decreased while the distance from the emitter increased. Chakraborty et al., (1998) also reported that soil water content was relatively higher by volume near the emitter and it was decreasing as the distance from the emitting point increased.

Apparently, ADI ( $\mathrm{T}_{6}$ and $\left.\mathrm{T}_{7}\right)$ practices resulted in uneven distribution of SMC from wetted area to dried area, indicating that the development and proliferation of roots were significantly prominent under wetting area compared to drier part (Sampathkumar et al., 2013).

The fully irrigated crop plants utilized water from top layers (upto $20 \mathrm{~cm}$ ) by extending roots laterally upto $25 \mathrm{~cm}$ and eventually more SMC and less variability was observed in deep layers. Similar results were reported by Arunadevi (2005) that the highest soil moisture percentage was recorded near the emitter point and it progressively decreased as the radial distance increased. In stressed plants, capillary movement of water from deep layers and vertical development of root caused low SMC and it varies with amount of water applied. Shirahatti et al., (2007) also reported the similar effect on SMC under different drip irrigation regimes.

Soil moisture content was lesser in the soil surface than in depth at different locations from emitter. Fully irrigated crop plants utilized water from top layers and eventually less variability was observed in deep layers. Decreasing SMC trend was noticed with treatments receiving less amount of water. Alternate deficit irrigation (ADI) concept exerted uneven distribution of moisture in the 
levels of both PE based irrigation application as well as $\mathrm{ET}_{\mathrm{c}}$ based.

\section{References}

Ah Koon, P.D., P.J. Gregory and J.P. Bell. 1990. Influence of drip irrigation emission rate on distribution and drainage of water beneath a sugar cane and a fallow plot. Agric. Water Manage. 17, 267-282.

Arunadevi. K. 2005. Performance evaluation of drip irrigation and fertigation on the yield and water use efficiency of mulberry. Ph.D. thesis, TNAU, Coimbatore.

Assouline, S. 2002. The Effects of micro drip and conventional drip irrigation on water distribution and uptake. Soil Sci. Soc. Am. J., 66, 1630-1636.

Bresler, E., B.L. Mc Neal and D.L. Carter. 1982. Saline and Sodic Soils. Advanced Series in Agricultural Sciences 10. Springer-Verlag, Berlin.

Chakraborty, D., A.K. Singh, A. Kumar, K.S. Uppal and M. Khanna. 1998. Effect of fertigation on nitrogen dynamics in Broccoli. In. Workshop on mlMicro Irrigation and Sprinkler Irrigation Systems, 28-30 April, 1998. New Delhi. Proceedings, Central Board of Irrigation and Power. Editors. C.V.J. Varma and A.R.G. Rao, Malcha Marg, New Delhi 21.

Crop production guide (CPG). 2012. Published by DEE. TNAU offset press. Coimbatore.

Farbrother, H. G. 1973. Water requirements of crops in the Gezira. Annual Report ofthe Gezira Research Station, 73: pp. 139 - 172.

Gencoglan, C., S. Gencoglan, H. Kirnak, C. Akbay and I. Boz. 2005. Deficit irrigation analysis of cotton under Harran conditions. Proceedings of the 4th GAP (Southeastern Anotolia
Project) Agricultural Congress, September 21-23, Turkey.

Kirda, C. 2002. Deficit irrigation scheduling based on plant growth stages showing water stress tolerance. In Deficit Irrigation Practice, 1-3 (Ed C. Kirda), Water Reports 22. Rome, Italy: FAO.

Philip, J.R. 1971. General theorem on steady infiltration from surface source with application to point and line source. Soil Science Society of American Proceedings. 35: 86-87.

Prichard, T., B. Hanson, L. Schwankl, P. Verdegaal and R. Smith. 2004. Deficit Irrigation of Quality of Wine Grapes Using Micro-Irrigation Techniques. Davis, CA: University of California Cooperative Extension, Department of Land, Air and Water Resources, University of California, $5 \mathrm{pp}$.

Sampathkumar, T., B.J. Pandian and S. Mahimairaja. 2012. Soil moisture distribution and root characters as influenced by deficit irrigation through drip system in cotton-maize cropping sequence. Agricultural Water Management 103:43-53

Shirahatti, M.S., C.J. Itnaland and D.S. Mallikarujunappa Gouda. 2007. Impact of differential methods of irrigation on yield levels of cotton in Red soils. Karnataka J. Agric. Sci., 20(1): 96-98

Sivanappan, K. 2004. Irrigation and rainwater management for improving water use efficacy and production in cotton crop. Proceedings of International Symposium on Strategies for Sustainable Cotton Production - A Global Vision, 23-25 November, UAS, Dharwad, Karnataka, India.

Sivanappan, R. K. 1998. Status, scope and future prospects of micro-irrigation in India. In: Proceedings of a workshop on micro irrigation and sprinkler Irrigation Systems, 28-30th April, 1998, New Delhi, India. pp: 1 - 7. 
Smith, M., D. Kivumbi and L.K. Heng. 2002. Use of the FAO CROPWAT Model in Deficit Irrigation Practice. Water Reports no. 22. Rome, Italy: Food and Agriculture Organization of the United Nations, pp. 17-28.

Veeraputhiran, R. 2000. Effect of Drip Irrigation and Fertigation on Growth and Yield of Hybrid Cotton. PhD thesis, Tamil Nadu Agricultural University, Coimbatore, India.
Vijayalakshmi, R. 2003. Micro-Sprinkler Irrigation and Fertigation and Land Configuration as a Best Management Technology Package for Groundnut. $\mathrm{PhD}$ thesis, Department of Agronomy, Agricultural College and Research Institute, Madurai, Tamil Nadu, India.

Zhang, Z. H., H.J. Cai and R.Y. Yang. 2004. Water requirements and crop coefficients of drip-irrigated crop under mulch in Minqin Vountry Oasis. Trans CSAE 20(5):97-100.

\section{How to cite this article:}

Bharathi A., T. Ragavan, V. Geethalakshmi, A. Rathinasamy and Amutha R. 2018. Soil Moisture Distribution as Influenced by Deficit Irrigation through Drip System in Maize. Int.J.Curr.Microbiol.App.Sci. 7(06): 1639-1646. doi: https://doi.org/10.20546/ijcmas.2018.706.195 